\title{
Information literacy as an advocacy tool by Indonesian school libraries: an APISI study
}

\author{
Hanna Chaterina George \\ Association of Indonesian School Information Professionals \\ (APISI-Asosiasi Pekerja Profesional Informasi Sekolah Indonesia) \\ Rumah Ndekem, Tanah Tingal, Jalan Merpati Raya No: 32 \\ Sawah Baru, Jombang, Ciputat, Tangerang Selatan 15413 \\ Banten, Indonesia \\ hanna@apisi.org
}

\begin{abstract}
This paper is a longer version and further elucidation of the version written for IFLA Conference entitled The role of national associations in advocating for school libraries: The case of Indonesia" by the author and Diljit Singh. It will outline in more detail APISI's study on information literacy. APISI is one of the nationally recognized library associations in Indonesia that has actively promoted information literacy as an advocacy tool. This paper will discuss APISI's history, program and activities. It describes the sequential development of events and studies of information literacy conducted over the years highlighting the importance of school libraries in Indonesia and the significant role that school librarians play in information literacy, independent learning and responsible citizenship. The goal of APISI is to formulate a long term advocacy strategy to benefit school communities and all school library stakeholders.
\end{abstract}

Keywords: Advocacy, APISI, Information literacy; School library association, Indonesia

\section{Introduction}

A Provincial Library and Archives Deputy was recently re-assigned as Chair of the Service Department of library, much to his colleagues' dismay. It was considered as a demotion and he was generally regarded as someone whose career has turned an adverse turn in his new role in the library. But contrary to what his colleagues and everybody else thought, the new Chair of the Service Department relished his new role. He was grateful with the new appointment and pleased to hold this new position and have direct contact with users (personal communication, April 20 2015).

As mentioned by Pendit, et.al (2013) that disrespect towards the profession is shown in the tendency toward placing "problematic teachers" as a librarians, as the two examples below:

- In 2009, Koran Tempo (19/01) reported that a teacher was relieved from classroom duties and appointed to head a school library after being implicated in a case involving 
harsh student disciplinary action. The appointment was considered as part of the punishment. (http://tinyurl.com/7y9snpt)

- The Suara Merdeka in 2012 published a report about similar case in which the appointment of a teacher as a librarian was considered "appropriate sanction" for breaching the ethical standard in teaching (http://tinyurl.com/85kakgb) (p.8)

Another recent report from a School Librarian in a private Catholic junior and high school in Makassar, South Sulawesi illustrates this point further. As a head of the library school, he was keen to know how much funding was allotted to the library annually to enable him to plan resourcing the library. He has not received a reply to his request to clarify budgetary allocation to the school library. Moreover, the Principal took it upon herself to buy copies of exercise books for the Science Olympic Competition for student representatives at the national level competition, clearly dissociating the library and the work of librarian with the life of the school (personal communication, April 24 2015). This is an evidence of what Pendit, et.al (2013) wrote that libraries are seldom considered part of teaching and their establishment at school level have always been hindered by scarcity of resources and funding (p.7)

This same School Librarian was challenged by an English teacher why the school library stocks fiction books and continues to acquire them. A healthy discussion was not possible as this teacher had preconceived ideas about books and libraries. Even so, for the care and effective management of the library, its collection and its users, this School Librarian received this year's Best Librarian Award as recognized by the National Library of the Republic of Indonesia. This, however, does not guarantee a smooth upward career path.

The reports above indicate how the role of librarians and school libraries are often put at a low priority by school management and, in some instances, even unrecognized. George and Singh (2014) stated this could be due to several factors to include the lack of understanding on the role of school libraries in education and lack of training among school librarians (p.1).

As professional librarians we believe that school library plays an important role in teaching and learning. It provides resources and services that facilitate the development of students' reading, academic achievement and lifelong learning (p.1). Some studies show that school libraries have an important contribution to the achievement of student learning The school library is central to learning and plays a key role in encouraging innovation, curiosity and problem solving (National Library of New Zealand, n.d.). In UNESCO/IFLA School Library Manifesto (1999), it is mentioned that the school library provides information and ideas that are fundamental to functioning successfully in today's information and knowledge-based society. The school library equips students with lifelong learning skills and develops the imagination, enabling them to live as responsible citizens.

Again, one of important roles of school library is as a hub for problem solving using information available in many formats. Research work done for completion of assigned tasks and school projects are examples of how thought processes are used in problem solving. This is where information literacy should be adopted in learning and teaching process. 
George and Singh (2014) stated that there is thus a need to advocate for school librarians so that they can be on the agenda of policy makers and administrators (p.1). One of the possible routes to gain more powerful voice in advocacy is via professional associations.

Professional association brings together members of similar profession for the development and advancement of their profession. There are several benefits derived from the activities of such organization, that is, to develop their knowledge and skills about school librarianship (George \& Singh, 2014: 5). In Indonesia, many teachers and school librarians are administrative personnel who do not have a background in library science. That is why they need to learn about the school library so that they can manage the library. Obviously they would be able to do so by participating in the workshops and events run by the associations, in the absence of formal training.

However, the effort above is insufficient for advocacy. There is still much work to be done on the school-community level and on the level of national associations. What is clear though is that national library associations should have established presence in regional level so that schools and school librarians can easily access support from them.

\section{Advocacy}

There is an urgent need for advocacy for school librarians. When the two reports of the 'problematic teachers' were made public, APISI enlisted fellow librarians and sympathizers to sign a petition to send to the school concerned and to the Ministry of Education and National Library (http://apisi.org/?s=Petisi) not to use the library as a punishment portal for erring teachers, thereby sending the wrong message as to its use. No reply was received. Advocacy efforts should not wait until a need arises or a crisis occurs (George and Singh, 2014:2).

A definition of advocacy developed by the AASL Advocacy Committee is that on-going process of building partnerships so that others will act for and with you, turning passive support into educated action for the library program. It begins with a vision and a plan for the library program that is then matched to the agenda and priorities of stakeholders (ALA). APISI sees that it is important to build partnerships as a process to make ourselves known. Many school librarians have carried their own advocacy individually by approaching their school principal and make their voices heard. Some efforts were successful, some were not. Therefore it is part of APISl's goal to plan better advocacy strategies.

\section{APISI}

APISI is an independent and non-profit professional organization run by Indonesian professional librarians. It was established on August 26, 2006 in Bogor, East Java. It was established during the third meeting of school librarians that started in October 2005. It was deemed necessary that a proper professional association be formed to accommodate and develop skills, competency and bargaining position of school librarians. APISI promotes school library as a center of learning and to maximize the role of information professionals. Therefore, APISI invites other professions to be involved such as library workers, publishers, writers, teachers, library software developers and many more who are interested in school librarianship and education to take part in developing school library's role in Indonesia. Each profession contributes their expertise and help prepare and direct students to become media 
and information literate and be responsible citizens, as shown in figure below (Latuputty \& Mulkan, 2011:9)

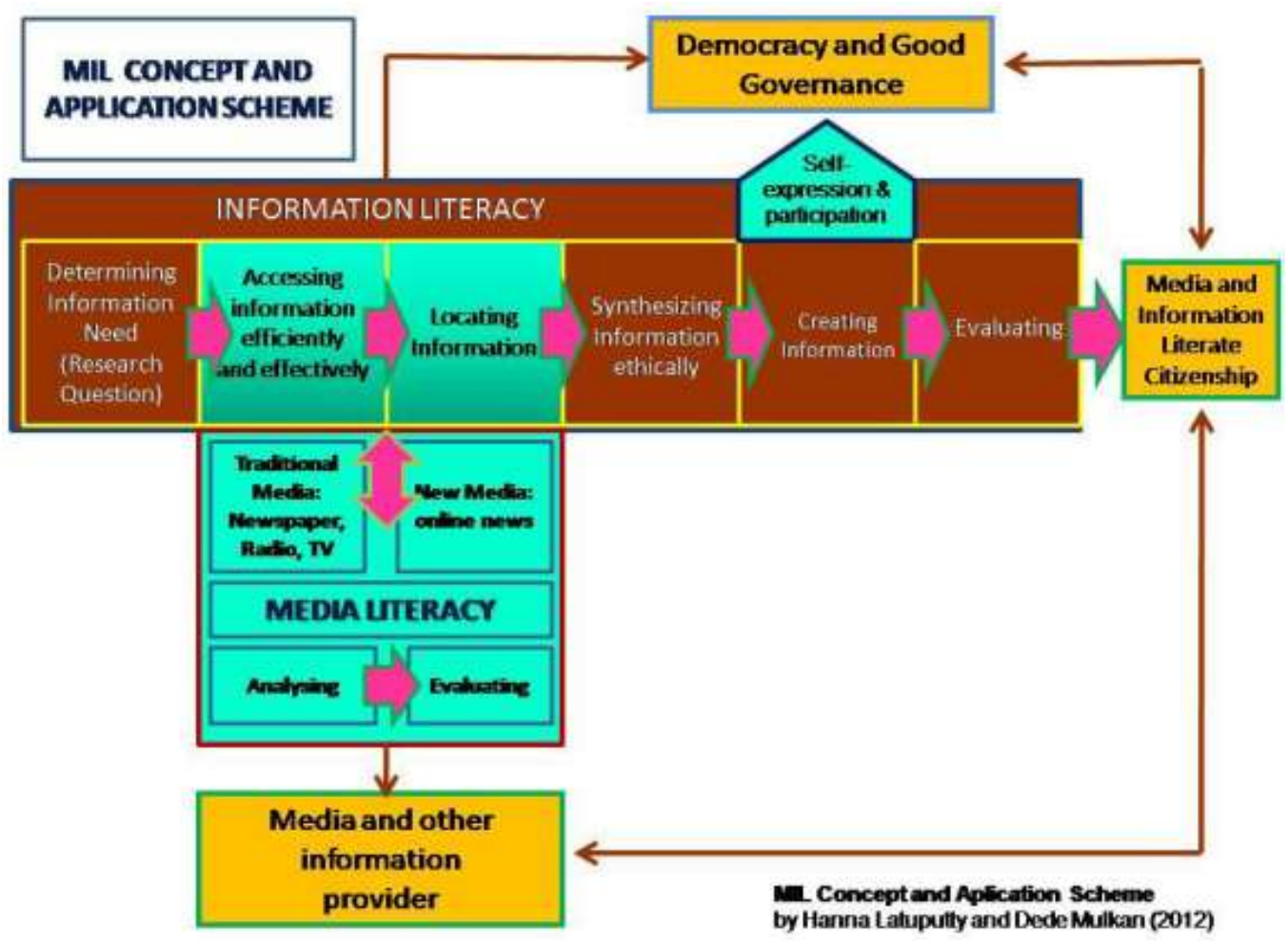

Figure 1. MIL Concept and Application Scheme

APISI uses the term Information Professionals instead of School Librarian since it promotes the new role of school librarians who are involved in information and knowledge management instead of other technical and administrative roles alone. The term also better reflects the service provided to students to prepare them to be independent learners. It takes adults around the environment of young people to support, teach and give them good models and to make good resources available in their learning. Parents act as models to develop children's reading habits, teachers encourage them to solve problems using a variety of information formats, and librarians teach them how to interact with information and be information literate.

\section{Information literacy in Indonesia}

APISI has made information literacy its main campaign drive since 2006. Information literacy road shows have been conducted in some big cities in Indonesia such as Jakarta, Bandung, Surabaya, Malang, Sukabumi, Bogor, Denpasar, Medan and Makassar. The roadshow highlighted the importance of information literacy in teaching and learning process in school and at home. The target audience of this roadshow were mainly school librarians, teachers and principals, although very few principals accepted the invitation to attend and participate, preferring instead to delegate to underlings. APISI sees the importance of the involvement of school principals in order for them to develop new thinking and new paradigm for their respective school libraries. APISI runs events at regular intervals such as short courses, 
seminars and consultancy. Almost always, information literacy and related topics are the main theme of these events. These events will be discussed and elaborated on in this paper as it also describes the understanding of the development of information literacy in Indonesia.

\section{Information literacy concept: APISI studies on information literacy}

\section{5 - Dearth of research on Information Literacy}

Ten years ago in 2005, the first information literacy research conducted in Indonesia funded by UNESCO. Diao and Chandrawati (2005) stated that:

the aims of this study were to assess the awareness and practices of information literacy in public schools in Jakarta; to identify the role, readiness, and requirements of school libraries in promoting information literacy and to develop suggestions for appropriate action plans for the involvement of school libraries in the development of an information literate society (p.ii).

As anticipated, the awareness of the importance of information literacy was poor. The study reported that some respondents believed vaguely that information literacy is an important element to support national curriculum but there was no clarity of view or understanding of how it is to be practiced (p.ii).

This lack of awareness was clearly demonstrated when none of the respondents (author's note: the respondents were school principals, teachers, librarians) had a full understanding of the information literacy concept. Among the respondents, the librarians had the least understanding of this concept (p.54). Related to the management's intervention as stakeholder who formulated library management policy, no clear statement in the school policy on information literacy implementation could be found although more than $50 \%$ of the principals in this study reported that they were. As a consequence of the lack of school's support and commitment on information literacy implementation, the development of library and information literacy program is stalled.

Poorly defined roles of librarians in schools and their lack of readiness in their jobs point to their insufficient knowledge of information literacy, and in turn points to inadequate training and lack of support internally (within schools) and externally (Ministry of Education, higher education authorities). There is an urgent need for good and effective training on information literacy, as well as commitment from school authorities to support policies to develop school librarians and to properly equip libraries to an acceptable standard (p.56)

Finally, this study was recommended as essential reading to decision makers such as school principals, education authorities and the UNESCO whose work in Indonesia covers information literacy. On the level of librarians and Information Professionals, it was suggested that librarians have to be made aware of their strategic position in information-rich environment. They need to be equipped and have the ability to train others and to work in partnership with teachers to make information literacy skills development and assessment integrated in the curriculum (p.57). Follow-up studies were also recommended.

The first meeting of school librarians in 2005, which was held in an international school, Tangerang, Banten, gave an opportunity for both researchers, Diao and Chandrawati to 
present their findings to participants. It was the first formal introduction of information literacy to a small group of school librarians.

\section{6 - First report on School Library and Information Literacy: Examples of information literacy implementation}

An invitation was extended to Indonesia to participate in the International Workshop on Information Literacy (IWIL) in Kuala Lumpur, Malaysia in 2006. Latuputty (2006) took this opportunity to prepare a country report to present in that workshop. The report highlighted that Indonesia has begun its implementation of information literacy in schools although there were areas for improvement that needed to be addressed at the first stage (p.16). Latuputty recommended that school principals and their management need to be aware and to understand the importance of school library in terms of supporting student's learning process (idem). The awareness of stakeholders such as school principal would then give enough support to build and develop the school library. At the same time, to give more qualified program in teaching information literacy, a proper training of information literacy is needed to equip librarian's skills. At the top level, stronger cooperation among Ministry of Education; National Library and Library Professional Associations to support any type of school library in Indonesia. Finally and more importantly, Latuputty mentioned that there is a need to design information literacy models based on the curriculum applied in various schools.

This presentation was conducted after the first and second meeting of school librarians mentioned above. At that time, a questionnaire was given to the participants and the questionnaire revealed that the information literacy application needs to be improved. The questionnaire further revealed that school's committee and principals need to know and understand that information literacy skills are important in enhancing students learning ability (Latuputty,2006:7).

\section{8 - Study on Schools' Lesson Plan and Information Literacy Aspects} Inspired by IWIL in Kuala Lumpur Malaysia in 2006, APISI submitted a proposal to IFLA/ALP to fund a similar event called Indonesian - Workshop on Information Literacy (IndonesianWIL). This workshop targeted representatives from selected provinces in Indonesia including some experts in education both from the academic community and practitioners from school libraries. The proposal was approved and a five-day workshop held in Bogor.

Workshop members reviewed some lesson plans made by teachers. These were chosen randomly from each school level: elementary, junior, secondary and vocational levels. There were four groups and each group studied the content of every lesson plan to see if information literacy was an integral part of it. The model used to hone the study process was Tujuh Langkah Literasi Informasi (Seven Steps to Information Literacy) developed by Ai Lien Diao et al. from Catholic University Atma Jaya, Jakarta. Some literacy experts from Malaysia, Singapore, Vietnam and Thailand were also invited.

The review of lessons plans in the workshop (APISI/IFLA,2008) indicated that no lesson plan included a full and complete strategy and stages towards achieving information literacy as spelled out in Diao and Chandrawati's study. The implementation of information literacy under this study showed that it was carried out in a certain structure within one semester. Based on the teaching and learning evaluation through the lesson plans mentioned above, there was a tendency for the teacher to be at the center of the process. The reason for this was that there were too many topics were to be completed in a semester. To ensure that all 
topics are covered, teachers preferred to complete the lessons by providing students with what they thought was sufficient information on all assigned topics, rather than giving students the opportunity to do their own study and research on each given topic in the library and to process what they have researched themselves. There was a tendency to skim through all topics but there was hardly any in-depth learning taking place.

This particular finding had librarians, teachers, principals, professional organization, National Library, Ministry of Education collaborating and working together in implementing information literacy in the Indonesian education system. The result has been documented and has been passed on to the Curriculum Department, Education Ministry with expectation that they will be considered for integration in the National Curriculum.

\section{1- Information Literacy is only applicable for international schools in Indonesia}

APISI has been fortunate to have the opportunity given by National Library to conduct a study to evaluate five years of information literacy campaign in Indonesia. This was important as the Department of National Education published Standard of Competencies for School Librarians as part of the Ministerial Decree No.25/2008. This standard recognizes information literacy as one of the competencies needed for both head of school library and its library staff.

This study examined how information literacy trained school librarians implemented information literacy in Indonesia. The aim of this study was to get an overview of school librarians' roles in implementing information literacy and the support received and obstacles encountered in the process (Latuputty, Wiyanti \& Widaty, 2011:5)

From the study, minimum requirements for each the key actors and the school policy were established:

- School Library. It should meet standard of collection, services and qualified staff

- School Principal. He/She should give full support and commitment to allocate sufficient and appropriate budget to develop the school library and for continuing professional development of librarian

- School policy. It must be stated in the school policy and understood by the school community that the school library is an important learning source and that teachers and librarians should collaborate in the learning and teaching of students (p. 41).

The supporting factor in implementing information literacy successfully included the school policy and support from school management. It would give positive impact if school principal instructed to organize information literacy program in school. The curriculum type applied in a school also contributed to the success of the information literacy drive. This study found that a curriculum that gave students opportunity to solve their problems using library resources have better chance to implement information literacy skills. Usually, students are assigned a project to complete in a certain subject. Their teachers, who may have information literacy in mind, would encourage them to finish the project using varied resource materials. Therefore, they would appreciate information literacy program taught both as library program and embedded in the subject teaching. This study showed that successful schools with information literacy program were schools with non-national curriculum and a dedicated and 
qualified librarian with a well-resourced school library. Most of all, a key to success depended on support from principal or school management.

\section{3 - Information Literacy: Socio-cultural context}

It was the first paper that analyzed information literacy from socio-cultural context. The authors agreed that the nature of information literacy is best revealed as situated practices in the learning process within a certain socio-cultural context that includes school social-setting and curriculum development. (Pendit, George \& Dhamayanti,2013:14)

The aspects of context in this sense are:

- working relationship between school librarians \& teachers

- how the library is perceived as a learning resources

- uncertainty surrounding librarians' position

- concept of "teacher librarian" is problematic

Therefore, the stipulation about integrating information literacy onto school curriculum appears to be a mission impossible.

It is suggested that professional associations such as APISI, ATPUSI, and IPI be active and work together in a coordinated approach to help school librarianship move forward. In particular, their active involvement in school curriculum development and teaching reformation is imperative, while the two formal institutions of the Department of Education and the National Library are best given the role of a catalyst to facilitate the reformation. At the same time and in the same vein, a major reform of education for library professionals, especially with regards to school librarians, will have to be conducted in earnest and in synchronized manner amongst the 13 (author's note: it is more than 20 now) existing library schools in Indonesia; their lack of orientation towards, and contribution to, school librarianships will only act as a further impediment. (p.14)

\section{3 - POLA LISA: An Information Literacy Model for National Schools in Indonesia} POLA means a pattern or a model. LISA stands for Literasi Informasi Santa Angela (information literacy of Santa Angela School Library). This model was constructed on the basis of research findings by George (2013). Initially, Santa Angela School Library (SA) was a school involved in pre-assessment for accreditation by National Library. On the appraisal form, SA answered that they have applied information literacy in a structured way. This fact became interesting as the previous APISI study in 2011 found that information literacy was only applicable for international schools, because usually they have well-resourced library staffed by qualified librarians. The school principal of this school supported the librarian in developing the library and to conduct the library's program. In a best case scenario, the school principal encouraged teachers to use the library for learning activities. This was rare in national-curriculum based schools in Indonesia and this piqued author's interest as a focus of research.

SA has two librarians and they have very good support from school principal. The library collection including reference, fiction and non-fiction collection, magazines and newspaper were up to date, computer facilities with internet connection at the second floor were available for students use, the study area was enough for one class to use. Teachers were 
asked to submit a library program at the end of school year to be implemented in the next year. Their library program included new students' orientation, reviews of journal articles, book reviews, silent reading and movie watching. Each class had regular visits that was timetabled by librarian every month. Moreover, there were many subject teachers who were sending their students to the library to complete assigned tasks and projects. This research found that the information literacy program at SA, as stated in the appraisal form was a program that was planned and applied during the school year. Meanwhile, the activities held were barely covering information literacy as a whole concept, such as formulating research questions using the information ethically and synthesizing information. Nevertheless, their program was a good start although there was room for improvement.

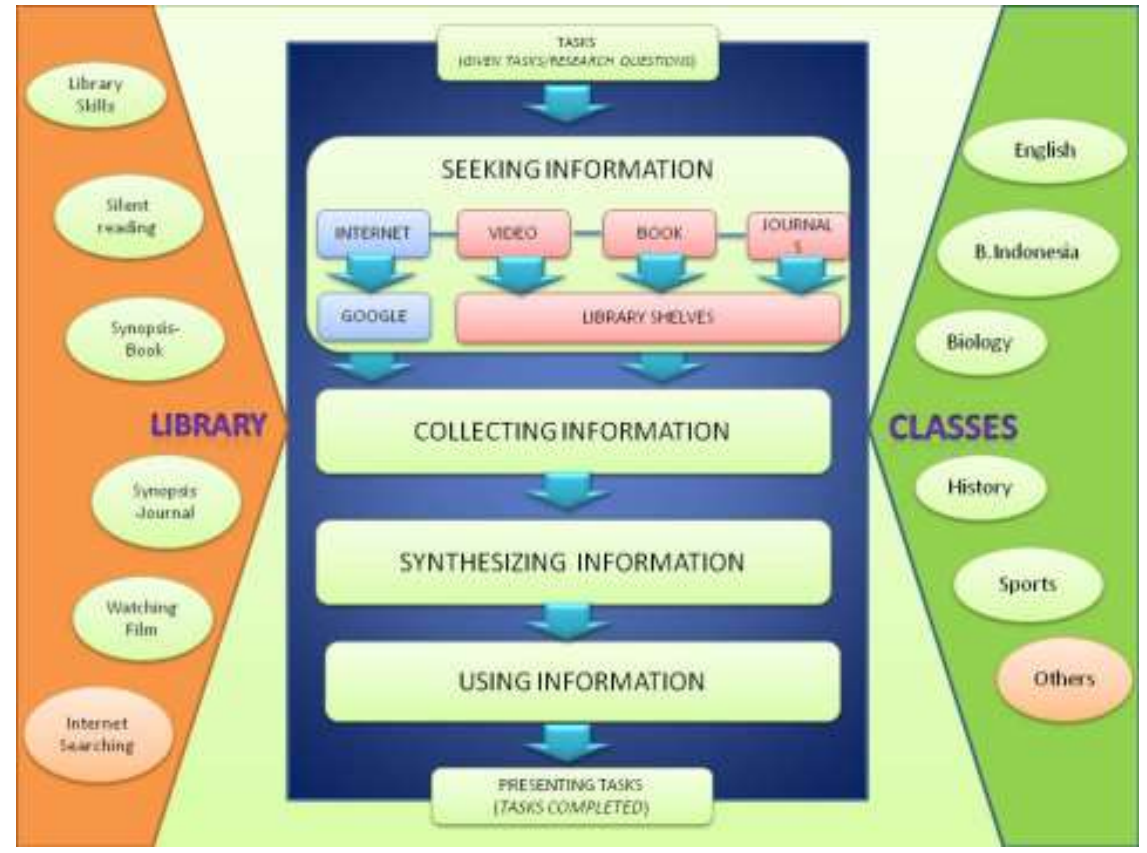

Figure 2. POLA LISA

The important key to the implementation of information literacy program in SA was due to the support of the school principal. She understood that the library is important by allocating appropriate funding to refresh their collection and facilities, and also encouraged teachers to use the library by allowing a certain period of time for their students to be in the library. She also listened to what librarians had to say in resourcing the library and gave her full support. The partnership between librarians and school principal was at its best. The library was freed from issues and problems regarding terms of policy in implementing its program. As a result, the library attracted many students, using it for reading or for doing their homework and borrowing from the collection.

The research recommended ways to improve information literacy program in SA. It was proposed that a more thorough and complete program be delivered such as learning to search information on the internet, how to use information ethically and how to synthesize information. Librarian needs to disseminate the information literacy steps to the teachers so that what was taught in the library is useful when students do their research tasks for the 
respective subjects. It will then involve more subject teachers to be aware and actively use the library for their learning process.

\section{Advocacy strategy through information literacy}

In his article, Horton (2011) mentioned that

"information literacy advocacy" means the actions that one takes to influence decision makers (whether policy makers in governments, business executives in private companies, or administrators in NGOs) to formally, officially, and publicly acknowledge, accept, and act upon proposed information literacy initiatives, in whatever form(s) they may be packaged-as plans, programs, projects, conferences, training workshops, seminars, colloquia, and so forth (p. 263).

Librarians in SA have shown that in adopting an information literacy program, they can effect changes as stated in Horton's definition of information literacy advocacy.

What was described in SA may not be a perfect model applicable to all school libraries but it serves as an example of a successful library program that supports information literacy. We may face many and difficult situations but in looking at SA's case, it was shown that difficulties can be overcome and a successful literacy program can be established given the right support.

Having engaged in the information literacy process and realizing the importance to advocate for it, some recommendations have been advanced for advocacy strategy through information literacy, as follows:

- Promote and maintain a sustained support of information literacy in as many schools as possible and initiated by school librarians. To facilitate a better understanding of the program, POLA LISA can be used as a model. If the concept of information literacy is understood and its importance recognized by every school principal, teachers, students and all stakeholders, then there is a better chance to established better resourced libraries in schools and staff them with qualified librarians and personnel.

- School librarians themselves need to continuously develop professionally in their knowledge of the program and of new technologies and to be proactive in the school community. Expanding the network to as many people, professions, publishers and local school library associations would also give a positive impact in the work place. Sharing and keeping contact with fellow school librarians will give librarians a boost and this larger network always comes in handy in the work at hand.

- Be consistent and preserve. (Horton,2011:272). Advocacy may need a lot of processing time. As long as there is an objective to be met and a goal to be reached, we will move forward to reach that objective and goal. 


\section{References}

American Library Association (ALA). Advocacy. AASL. American Association of School Librarians. Retrieved April 7, 2015 from http://www.ala.org/aasl/advocacy/definitions

APISI \& IFL/ALP. 2008. Aplikasi Literasi Informasi dalam Kurikulum Nasional (KTSP): Contoh Penerapan untuk Tingkat Sd, SMP dan SMA. Hasil Diskusi Indonesian Workshop on Information Literacy. Bogor: CICO

Diao, Ai Lien, \& Titi Chandrawati. 2005. Current State of Information Literacy Awareness and Practices in Indonesian Primary and Secondary Public Schools. Jakarta: Atma Jaya Catholic University Library \& Faculty of Education - Open University

George, Hanna Chaterina and Singh, Diljit (2014) The role of national associations in advocating for school libraries: The case of Indonesia. Paper presented at: IFLA WLIC 2014 - Lyon - Libraries, Citizens, Societies: Confluence for Knowledge in Session 213 - School Libraries. In: IFLA WLIC 2014, 16-22 August 2014, Lyon, France.

George, H. C. (2012). Literasi Informasi Perpustakaan Sekolah : Studi KasusPenerapan Program Literasi Informasi di Perpustakaan Sekolah Santa Angela Bandung. Bandung : Universitas Padjadjaran, pp. 135-160.

Horton, Forest Woody, Jr . 2011. Information Literacy Advocacy-Woody's Ten Commandments. Library Trends "Information Literacy Beyond The Academy, Part 1: Towards Policy Formulation ed. by John Crawford" 60 (2),262-276. Retrieved April 12, 2015 from https://www.ideals.illinois.edu/bitstream/handle/2142/31876/60.2.horton.pdf?seque $\underline{\text { nce }=2}$

Latuputty, Hanna \& Dede Mulkan. 2012. Developing a Media and Information Literacy program: a MIL program guide for teachers and librarians in Elementary School in Indonesia . In CONSAL Proceedings. Bali. Retrieved April 142014 from http://consalxv.perpusnas.go.id/uploaded files/pdf/papers/normal/ID HANNA DE DE MedialnformationLiteracy fullpaper.pdf

Latuputty, H. C., M.I. Eko Wiyanti, and Dwi Retno Widaty (2011). Peran Tenaga Perpustakaan Sekolah dalam Implementasi Literasi Informasi di Indonesia: kajian terhadap tenaga perpustakaan sekolah yang telah mengikuti pelatihan literasi informasi, Jakarta : Pusat Pengembangan Perpustakaan \& Pengkajian Minat Baca, Deputi Bidang Pengembangan Sumber Daya Perpustakaan, Perpustakaan Nasional RI.

Latuputty, Hanna. 2006. Information Literacy in Indonesia: a Challenge to Make a Brighter Future. Paper presented at International Workshop on Information Literacy in Kuala Lumpur, Malaysia

Latuputty, H. C., Wiyanti, Eko M.I and Widaty, Dwi Retno (2011). Peran Tenaga Perpustakaan Sekolah dalam Implementasi Literasi Informasi di Indonesia: kajian 
terhadap tenaga perpustakaan sekolah yang telah mengikuti pelatihan literasi informasi, Jakarta : Pusat Pengembangan Perpustakaan \& Pengkajian Minat Baca, Deputi Bidang Pengembangan Sumber Daya Perpustakaan, Perpustakaan Nasional RI.

National Library of New Zealand. (n.d.). School library: Purpose. Retrieved from http://schools.natlib.govt.nz/supporting-learners/effective-practice/school-librarypurpose

UNESCO/IFLA School Library Manifesto. (1999). Available at Retrieved 12 June 2014 from http://www.unesco.org/webworld/libraries/manifestos/school manifesto.html 